Article

\title{
Activation of the Nuclear Factor E2-Related Factor 2 Pathway by Novel Natural Products Halomadurones A-D and a Synthetic Analogue
}

Thomas P. Wyche, Miranda Standiford, Yanpeng Hou, Doug Braun, Delinda A. Johnson, Jeffrey A. Johnson and Tim S. Bugni *

Pharmaceutical Sciences Division, University of Wisconsin-Madison, 777 Highland Avenue, Madison, WI 53705, USA; E-Mails: twyche@wisc.edu (T.P.W.); standiford@wisc.edu (M.S.); yanpenghou@gmail.com (Y.H.); drbraun1@facstaff.wisc.edu (D.B.); dajohnson@pharmacy.wisc.edu (D.A.J.); jajohnson@pharmacy.wisc.edu (J.A.J.)

* Author to whom correspondence should be addressed; E-Mail: tbugni@pharmacy.wisc.edu; Tel.: +1-608-263-2519; Fax: +1-608-262-5345.

Received: 22 October 2013; in revised form: 13 November 2013 / Accepted: 3 December 2013 / Published: 16 December 2013

\begin{abstract}
Two novel chlorinated pyrones, halomadurones $\mathrm{A}$ and $\mathrm{B}$, and two novel brominated analogues, halomadurones $\mathrm{C}$ and $\mathrm{D}$, were isolated from a marine Actinomadura sp. cultivated from the ascidian Ecteinascidia turbinata. Additionally, a non-halogenated analogue, 2-methyl-6-((E)-3-methyl-1,3-hexadiene)- $\gamma$-pyrone, was synthesized to understand the role of the halogens for activity. Halomadurones $\mathrm{C}$ and $\mathrm{D}$ demonstrated potent nuclear factor E2-related factor antioxidant response element (Nrf2-ARE) activation, which is an important therapeutic approach for treatment of neurodegenerative diseases.
\end{abstract}

Keywords: Ecteinascidia turbinata; halomadurones; Actinomadura; nuclear factor E2-related factor antioxidant response element

\section{Introduction}

The prevalence of neurodegenerative diseases, such as Alzheimer's disease (AD), Parkinson's disease, Huntington's disease, and amyotrophic lateral sclerosis (ALS) is on the rise worldwide [1-3]; cases of $\mathrm{AD}$, the most common neurodegenerative disease, are projected to reach 115 million by the year 2050 [3]. Meanwhile, only a handful of therapeutics are available that target these diseases, most 
of which only treat the symptoms not the underlying cause. Many neurodegenerative diseases are caused by mitochondrial DNA mutation or oxidative stress damage [4]. Therefore, determining methods of minimizing oxidative stress is a potential strategy towards preventing many neurodegenerative diseases $[5,6]$.

The transcription factor Nrf2 (nuclear factor E2-related factor) activates the antioxidant response element (ARE), which is located in the promoter region of genes that encode cytoprotective and antioxidant enzymes including many phase II detoxification enzymes [7-9]. Therefore, activation of Nrf2 represents a promising therapeutic strategy for combatting neurodegenerative diseases. In order to identify activators of this pathway in conjunction with having an in vivo model for evaluating therapeutics for neurodegenerative diseases, a transgenic mouse model was created that contained a human placental alkaline phosphatase reporter under the control of the ARE. For in vitro testing, primary neuronal cells from ARE-hPAP transgenic reporter were used to test for Nrf2/ARE activation [10,11]. The use of primary neuronal cells has provided an in vitro model that most closely resembles the in vivo pathology, albeit without the blood brain barrier. In parallel, the 3-(4,5-dimethylthiazol-2-yl)-5(3-carboxymethoxyphenyl)-2-(4-sulfophenyl)-2H-tetrazolium inner salt (MTS) assay can be used to test toxicity of the compounds. There have been only limited reports on natural product pharmacophores that activate the Nrf2/ARE pathway. The vast majority have been electrophiles, such as Michael acceptors [12-16]. More recently, activation of the Nrf2-ARE pathway with small molecules was also investigated by Luesch and co-workers leading to the discovery of Nrf2-ARE activators from seaweed extracts [17] and an electrophile ARE activator with in vivo activity [16].

In our pursuit of Nrf2/ARE activators, we isolated four novel halogenated electrophilic polyketides that were named halomadurones A-D (1-4) (Figure 1), from a marine Actinomadura sp. (Strain WMMB499) cultivated from the ascidian Ecteinascidia turbinata (Herdman, 1880). Halomadurones C (3) and D (4) demonstrated potent nuclear factor E2-related factor antioxidant response element (Nrf2-ARE) activation in the ARE-hPAP assay. The cytotoxicity studies and activity in the ARE-hPAP assay was suggestive of a narrow therapeutic window. Synthesis of a non-halogenated pyrone demonstrated that bromination was a key feature of the pharmacophore.

Figure 1. Structures of 1-5.
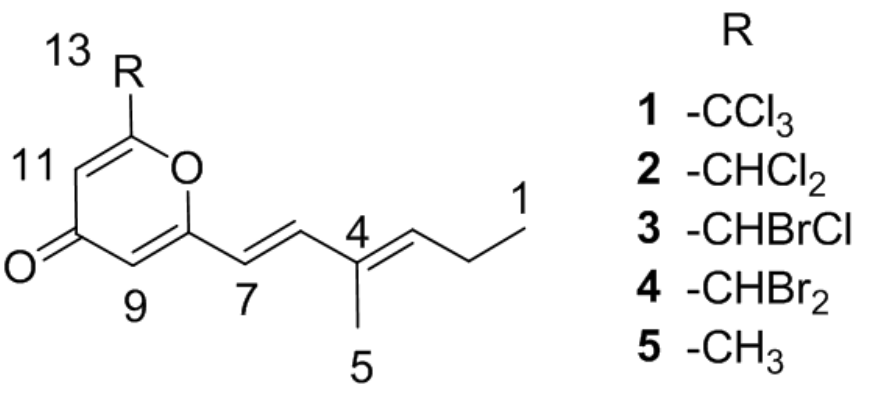

In addition to the promising in vitro activity, halomadurones A-D (1-4) represent a new carbon skeleton due to the position of the methyl group. Additionally, halomadurone A (1), contains a trichloromethyl group, which is a rare moiety in natural products. Most natural products that contain a trichloromethyl group, such as barbamide A [18] and dysidenamide [19], were isolated from cyanobacteria and also contain a thiazole ring. However, cytotoxic trichlorinated polyenones neocarzilin A and B [20] 
were produced by the soil-derived bacterium Streptomyces carzinostaticus and do not contain a thiazole ring. Consequently, neocarzilins $\mathrm{A}$ and $\mathrm{B}$, which have been the target for various synthetic [21] and biosynthetic studies [22], are now joined by halomadurone A (1) as the sole members of actinomycete-derived trichlorinated natural products. The role of the trichloromethyl group in bioactivity was investigated with halomadurones A-D (1-4) and a non-halogenated analogue, 2-methyl-6-((E)-3-methyl-1,3-hexadiene)- $\gamma$-pyrone (5), which we synthesized.

\section{Results and Discussion}

\subsection{Bacterial Strain Selection and Structure Elucidation}

Our attention was drawn to strain WMMB499 after analysis of thirty-four marine-derived bacterial extracts using LCMS-based metabolomics relying on principal component analysis (PCA) [23]. When compared to the other 33 LCMS chromatograms using PCA, WMMB499 was identified as having unique chemical signatures and putative novel natural products; after saline fermentation and isolation, WMMB499 was found to produce halomadurones A (1) and B (2). Halomadurones C (3) and D (4) were produced by WMMB499 by increasing the ratio $\mathrm{KBr} / \mathrm{NaCl}$. Previous studies have demonstrated that many halogenases are promiscuous with respect to using $\mathrm{Br}$ and $\mathrm{Cl}[24,25]$.

HRMS supported the molecular formula of $\mathrm{C}_{13} \mathrm{H}_{13} \mathrm{Cl}_{3} \mathrm{O}_{2}$ and $\mathrm{C}_{13} \mathrm{H}_{14} \mathrm{Cl}_{2} \mathrm{O}_{2}$ for halomadurone $\mathrm{A}$ (1) and $\mathrm{B}$ (2), respectively. Analysis of ${ }^{1} \mathrm{H}$ and ${ }^{13} \mathrm{C}$ NMR data (Table 1, Figure S1-S12) allowed for determination of the structures of halomadurones $\mathrm{A}(\mathbf{1})$ and $\mathrm{B}(\mathbf{2})$. The ${ }^{1} \mathrm{H}$ and ${ }^{13} \mathrm{C} \mathrm{NMR}$ data for halomadurone A (1) supported the conclusion that C-13 was connected to only one carbon, and in combination with the ${ }^{13} \mathrm{C}$ chemical shift at C-13 (90.3 ppm) and molecular formula, allowed for the assignment of the trichloromethyl group. A large vicinal coupling constant $\left({ }^{3} J_{\mathrm{H}} 15.6\right)$ for H-6 and H-7 supported the assignment of the $E$ conformation [26]. ROESY NMR data allowed for the assignment of the $E$ olefin at C-3 and C-4 (Figure S13). A comparison of ${ }^{1} \mathrm{H}$ and ${ }^{13} \mathrm{C}$ NMR shifts between halomadurones $\mathrm{A}(1)$ and $\mathrm{B}(2)$ showed that the only difference between the two structures was at C-13. C-13 in halomadurone B (2) contained two chlorine atoms and one hydrogen as evidenced by the upfield shift of $\mathrm{C}-13$ to $65.8 \mathrm{ppm}$ and a methine proton at $6.35 \mathrm{ppm}$. The relative configuration of the two olefins was assigned the same as halomadurone A (1) on the basis of vicinal coupling constants and ROESY NMR data.

After the structural elucidation of halomadurones $\mathrm{A}(\mathbf{1})$ and $\mathrm{B}(\mathbf{2})$, the amount of $\mathrm{KBr}$ was increased from $0.1 \mathrm{~g} / \mathrm{L}$ to $10 \mathrm{~g} / \mathrm{L}$ and $\mathrm{NaCl}$ was reduced from $20 \mathrm{~g} / \mathrm{L}$ to $0 \mathrm{~g} / \mathrm{L}$ in fermentation medium ASW-A, resulting in the production of brominated analogues. Many halogenases have low specificity for the halide substrate, and the incorporation of a specific halogen often depends on the relative concentration of each halogen anion in the fermentation medium [27,28]. HRMS of the two brominated analogues, halomadurones $\mathrm{C}$ (3) and $\mathrm{D}(4)$, supported the molecular formulas of $\mathrm{C}_{13} \mathrm{H}_{14} \mathrm{BrClO}_{2}$ and $\mathrm{C}_{13} \mathrm{H}_{14} \mathrm{Br}_{2} \mathrm{O}_{2}$, respectively. A comparison of the ${ }^{1} \mathrm{H}$ and ${ }^{13} \mathrm{C}$ NMR shifts (Table 1, Figure S14-S25) of halomadurones $\mathrm{C} \mathrm{(3)}$ and D (4) with halomadurone B (2) confirmed that the only difference in the structures was the halogenated atoms at $\mathrm{C}-13$. The relative configuration of the two olefins for halomadurones C (3) and D (4) was assigned the same as halomadurone A (1) on the basis of vicinal coupling constants and ROESY NMR data. The lack of optical rotation by halomadurone C (3) suggested that a racemic mixture of both enantiomers existed. 
Table 1. ${ }^{1} \mathrm{H}$ and ${ }^{13} \mathrm{C}$ NMR data for $\mathbf{1}-\mathbf{4}\left(600 \mathrm{MHz}\right.$ for ${ }^{1} \mathrm{H}, 150 \mathrm{MHz}$ for $\left.{ }^{13} \mathrm{C}, \mathrm{CDCl}_{3}\right)$.

\begin{tabular}{|c|c|c|c|c|c|c|c|c|}
\hline \multirow{2}{*}{ No. } & \multicolumn{2}{|c|}{1} & \multicolumn{2}{|c|}{2} & \multicolumn{2}{|c|}{3} & \multicolumn{2}{|c|}{4} \\
\hline & $\delta_{\mathrm{C}}$, mult. & $\delta_{\mathrm{H}}(J$ in $\mathrm{Hz})$ & $\delta_{\mathrm{C}}$, mult. & $\delta_{\mathrm{H}}(J$ in $\mathrm{Hz})$ & $\delta_{\mathrm{C}}$, mult. & $\delta_{\mathrm{H}}(J$ in $\mathbf{H z})$ & $\delta_{\mathrm{C}}$, mult. & $\delta_{\mathrm{H}}(J$ in $\mathrm{Hz})$ \\
\hline 1 & $13.8, \mathrm{CH}_{3}$ & $1.04, \mathrm{t}(7.3)$ & $13.8, \mathrm{CH}_{3}$ & $1.04, \mathrm{t}(7.3)$ & $13.8, \mathrm{CH}_{3}$ & $1.04, \mathrm{t}(7.5)$ & $13.8, \mathrm{CH}_{3}$ & $1.05, \mathrm{t}(7.5)$ \\
\hline 2 & $22.4, \mathrm{CH}_{2}$ & 2.24 , qn (7.3) & $22.4, \mathrm{CH}_{2}$ & 2.24 , qn (7.3) & $22.4, \mathrm{CH}_{2}$ & 2.24, qn $(7.5)$ & $22.5, \mathrm{CH}_{2}$ & 2.24, qn (7.5) \\
\hline 3 & $144.3, \mathrm{CH}$ & $5.93, \mathrm{t}(7.3)$ & 144.0, CH & $5.92, \mathrm{t}(7.3)$ & 144.0, $\mathrm{CH}$ & $5.93, \mathrm{t}(7.2)$ & 144.0, CH & $5.94, \mathrm{t}(7.5)$ \\
\hline 4 & $132.6, \mathrm{C}$ & & 132.6, C & & 132.7, C & & $132.7, \mathrm{C}$ & \\
\hline 5 & $12.2, \mathrm{CH}_{3}$ & $1.82, \mathrm{~s}$ & $12.2, \mathrm{CH}_{3}$ & $1.82, \mathrm{~s}$ & $12.2, \mathrm{CH}_{3}$ & $1.82, \mathrm{~s}$ & $12.2, \mathrm{CH}_{3}$ & $1.82, \mathrm{~s}$ \\
\hline 6 & $143.3, \mathrm{CH}$ & $7.14, \mathrm{~d}(15.6)$ & $142.9, \mathrm{CH}$ & 7.14, d (15.6) & $142.9, \mathrm{CH}$ & $7.14, \mathrm{~d}(15.8)$ & $142.9, \mathrm{CH}$ & 7.17, d (15.8) \\
\hline 7 & $115.8, \mathrm{CH}$ & $6.07, \mathrm{~d}(15.6)$ & $116.1, \mathrm{CH}$ & $6.07, \mathrm{~d}(15.6)$ & $116.2, \mathrm{CH}$ & $6.04, \mathrm{~d}(15.8)$ & 116.3, CH & $6.05, \mathrm{~d}(15.8)$ \\
\hline 8 & $163.2, \mathrm{C}$ & & $162.9, \mathrm{C}$ & & $163.4, \mathrm{C}$ & & $163.4, \mathrm{C}$ & \\
\hline 9 & $112.3, \mathrm{CH}$ & $6.17, \mathrm{~d}(1.8)$ & 112.7, CH & $6.17, \mathrm{~d}(2.0)$ & $112.2, \mathrm{CH}$ & $6.14, \mathrm{~d}(2.3)$ & $113.1, \mathrm{CH}$ & $6.13, \mathrm{~d}(2.3)$ \\
\hline 10 & $179.5, \mathrm{C}$ & & $179.5, \mathrm{C}$ & & 179.6, C & & $179.5, \mathrm{C}$ & \\
\hline 11 & $111.8, \mathrm{CH}$ & $6.85, \mathrm{~d}(1.8)$ & 112.7, $\mathrm{CH}$ & $6.42, \mathrm{~d}(2.0)$ & $112.1, \mathrm{CH}$ & $6.39, \mathrm{~d}(2.3)$ & $111.4, \mathrm{CH}$ & $6.32, \mathrm{~d}(2.3)$ \\
\hline 12 & $160.5, \mathrm{C}$ & & $160.2, \mathrm{C}$ & & $160.7, \mathrm{C}$ & & $160.8, \mathrm{C}$ & \\
\hline 13 & $90.3, \mathrm{C}$ & & $65.8, \mathrm{CH}$ & $6.35, \mathrm{~s}$ & $50.1, \mathrm{CH}$ & $6.35, \mathrm{~s}$ & $32.5, \mathrm{CH}$ & $6.24, \mathrm{~s}$ \\
\hline
\end{tabular}




\subsection{Synthetic Analogue}

After isolation and structure elucidation of halomadurones A-D (1-4), a non-halogenated analogue, 2-methyl-6-((E)-3-methyl-1,3-hexadiene)- $\gamma$-pyrone (5) was synthesized to compare the bioactivity of the novel structures (Scheme 1). In particular, the effect of substitution on the pyrone methyl was investigated. 2-6-Dimethyl- $\gamma$-pyrone in sodium ethoxide was added to 2-methyl-2-pentenal and stirred at room temperature for 5 hours [29]. Purification of the product (see Experimental Section) resulted in $4.0 \mathrm{mg}$ 2-methyl-6-((E)-3-methyl-1,3-hexadiene)- $\gamma$-pyrone (5). The structure was confirmed by analysis of ${ }^{1} \mathrm{H}$ and ${ }^{13} \mathrm{C}$ NMR and MS data (Table S1, Figure S26-S31). ROESY NMR data and vicinal coupling constants confirmed the assignment of the $E$ olefin at C-3 and C-4. Although sufficient compound yield was achieved for initial in vitro studies, the overall yield was low ( $2 \%)$ as expected.

Scheme 1. Synthesis of 5.
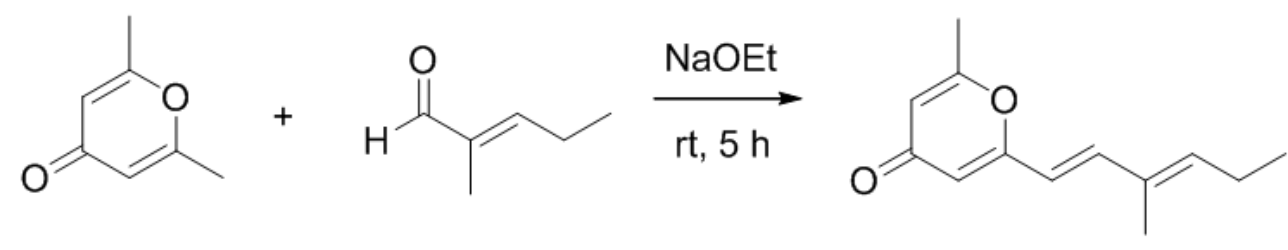

5

\subsection{Biological Activity}

On the basis of structural motifs that were present in other natural product activators, we hypothesized that the halomadurones could be activators and would contribute further knowledge surrounding SAR. Therefore, halomadurones A-D (1-4) and 2-methyl-6-((E)-3-methyl-1,3-hexadiene)- $\gamma$-pyrone (5) were evaluated for Nrf2-ARE activation (Figure 2). Tert-butylhydroquinone ( $t \mathrm{BHQ}$ ) was used as a positive control. Halomadurones C (3) and D (4) demonstrated potent Nrf2-ARE activation in the hPAP assay, but toxicity was apparent at higher concentrations (Figure 2). Nrf2 activation did not increase in a dose-dependent manner with increasing concentrations of halomadurones $C(3)$ and D (4) due to cytotoxicity. For example, treatment with concentrations of 7.5 and $15 \mu \mathrm{M}$ resulted in greater Nrf2 activation than treatment with $30 \mu \mathrm{M}$. This decrease in activation at higher concentrations of halomadurones $\mathrm{C}(3)$ and $\mathrm{D}(4)$ correlated with an increase in cytotoxicity indicative of a narrow therapeutic window. More specifically, halomadurone D (4) had a dramatic decrease in hPAP activity at $30 \mu \mathrm{M}$ in comparison to halomadurone $\mathrm{C}(3)$; yet, halomadurone D (4) had greater hPAP activity than halomadurone $\mathrm{C}$ (3) at 15 and $7.5 \mu \mathrm{M}$. Halomadurones $\mathrm{A}$ (1) and $\mathrm{B}$ (2) and 2-methyl-6-((E)-3-methyl-1,3-hexadiene)- $\gamma$-pyrone (5) demonstrated less than a ten-fold increase in Nrf2-ARE activation, considerably less than $t$ BHQ. The four halogenated pyrones (1-4) demonstrated greater Nrf2 activation than the non-halogenated pyrone (5), suggesting the importance of the halogen atoms in their activity. Among the halogenated pyrones, brominated halomadurones C (3) and D (4) demonstrated a considerable increase in activation compared to chlorinated halomadurones A (1) and B (2), potentially due to the increased electrophilicity from the bromine atoms. However, at higher concentrations, electrophiles sometimes react with thiol groups, which can lead to toxicity [30]. 
Neuroprotection assays were conducted for halomadurone C (3) and D (4) at $3 \mu \mathrm{M}$, but neither compound demonstrated neuroprotection.

Figure 2. Nrf2 activation and cytotoxicity of 1-5. Primary cortical cultures were prepared and treated with vehicle or compounds at increasing concentrations for $48 \mathrm{~h}$. (a) hPAP activity was measured. All values are standardized to the vehicle treated value and presented as fold change; Mean \pm SEM. (b) Cell viability was assessed using MTS assay. All values are standardized to the vehicle treated value and presented as percent of Mean $\pm \mathrm{SEM}$.

hPAP

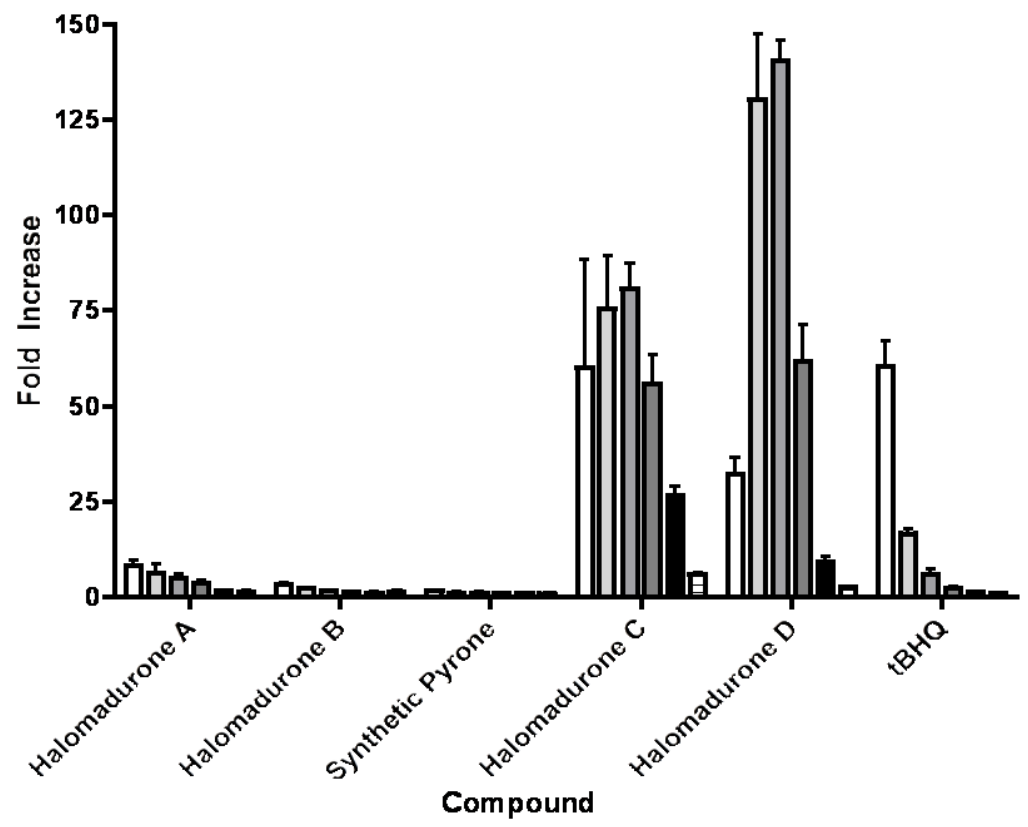

(a)

MTS

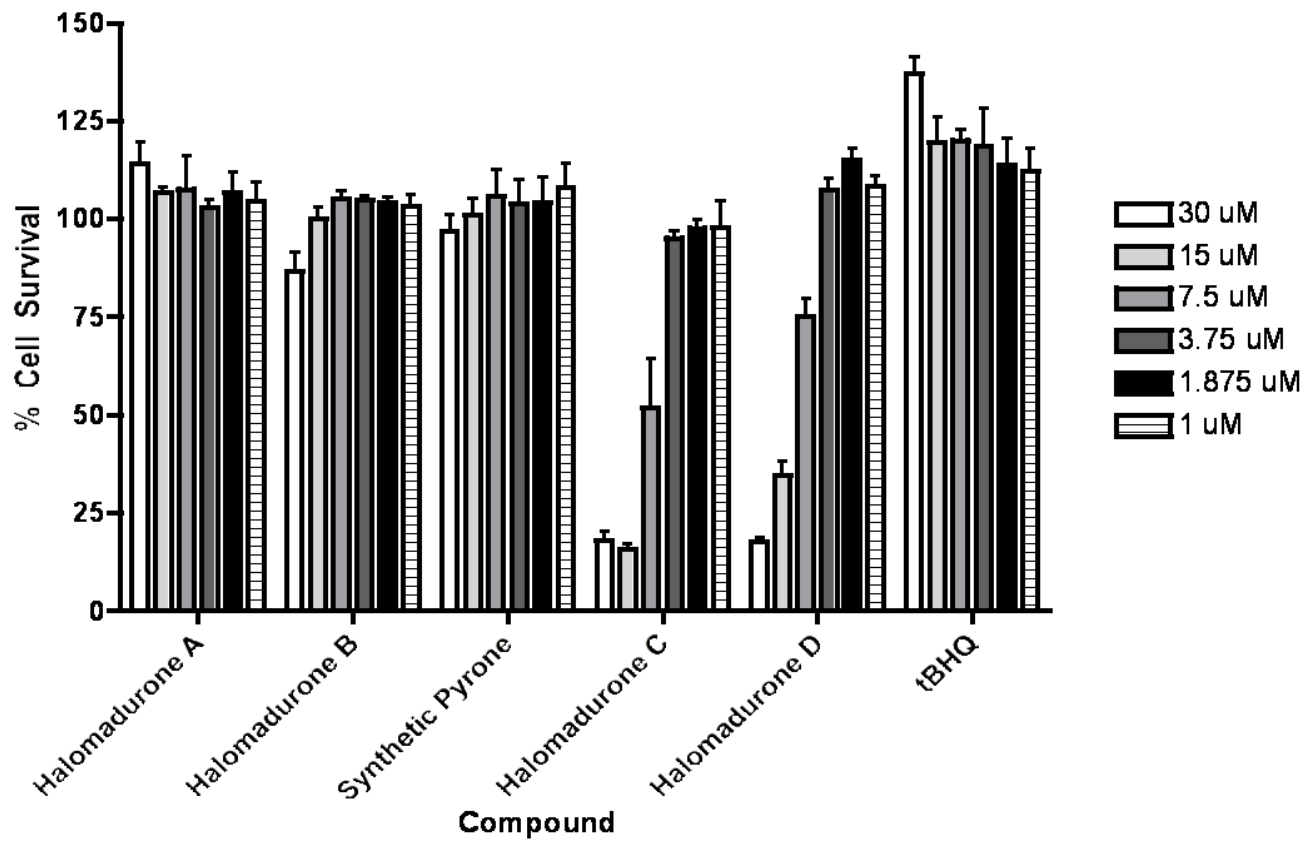

(b) 


\section{Experimental Section}

\subsection{General Experimental Procedures}

Optical rotations were measured on a Perkin-Elmer 241 Polarimeter. UV spectra were recorded on an Aminco/OLIS UV-Vis spectrophotometer. IR spectra were measured with a Bruker Equinox 55/S FT-IR spectrophotometer. NMR spectra were obtained in $\mathrm{CDCl}_{3}$ with a Bruker Avance $600 \mathrm{MHz}$ spectrometer equipped with a $1.7 \mathrm{~mm}{ }^{1} \mathrm{H}\left\{{ }^{13} \mathrm{C} /{ }^{15} \mathrm{~N}\right\}$ cryoprobe, a Bruker Avance $500 \mathrm{MHz}$ spectrometer equipped with a ${ }^{13} \mathrm{C} /{ }^{15} \mathrm{~N}\left\{{ }^{1} \mathrm{H}\right\}$ cryoprobe, and a Varian Unity-Inova $500 \mathrm{MHz}$ spectrometer. HRMS data were acquired with a Bruker MaXis 4G QTOF mass spectrometer. RP HPLC was performed using a Shimadzu Prominence HPLC system and a Phenomenex Onyx Monolithic C18 column $(100 \times 4.6 \mathrm{~mm})$.

\subsection{Biological Material}

Ascidian specimens were collected on 10 August 2011, in the Florida Keys $\left(24^{\circ} 39.591^{\prime}\right.$, $81^{\circ} 25.217^{\prime}$ ). A voucher specimen (FLK10-5-6) for Ecteinascidia turbinata (Herdman, 1880) is housed at the University of Wisconsin-Madison. For cultivation, a sample of ascidian $\left(1 \mathrm{~cm}^{3}\right)$ was rinsed with sterile seawater, macerated using a sterile pestle in a micro-centrifuge tube, and dilutions were made in sterile seawater, with vortexing between steps to separate bacteria from heavier tissues. Dilutions were separately plated on three media: ISP2, R2A, and M4. Each medium was supplemented with $50 \mu \mathrm{g} / \mathrm{mL}$ cycloheximide and $25 \mu \mathrm{g} / \mathrm{mL}$ nalidixic acid. Plates were incubated at $28{ }^{\circ} \mathrm{C}$ for at least 28 days, and strain WMMB499 was purified from an ISP2 isolation plate.

\subsection{Sequencing}

16S rDNA sequencing was conducted as previously described [31]. WMMB499 was identified as an Actinomadura sp. and demonstrated 99\% sequence similarity to Actinomadura sp. 13679C (accession number EU741239). The 16S sequence for WMMB499 was deposited in GenBank (accession number JX101467).

\subsection{Fermentation, Extraction, and Isolation}

Two $10 \mathrm{~mL}$ seed cultures $(25 \times 150 \mathrm{~mm}$ tubes $)$ in medium ASW-A (20 g soluble starch, $10 \mathrm{~g}$ glucose, $5 \mathrm{~g}$ peptone, $5 \mathrm{~g}$ yeast extract, $5 \mathrm{~g} \mathrm{CaCO}_{3}$ per liter of artificial seawater) were inoculated with strain WMMB499 and shaken (200 RPM, $28^{\circ} \mathrm{C}$ ) for seven days. Two hundred fifty $\mathrm{mL}$ baffled flasks $(12 \times 50 \mathrm{~mL})$ containing ASW-A were inoculated with $1 \mathrm{~mL}$ seed culture and were incubated $\left(200 \mathrm{RPM}, 28^{\circ} \mathrm{C}\right)$ for seven days. Two-liter flasks $(6 \times 500 \mathrm{~mL})$ containing medium ASW-A with Diaion HP20 (4\% by weight) were inoculated with $25 \mathrm{~mL}$ from the $50 \mathrm{~mL}$ culture and shaken (200 RPM, $28{ }^{\circ} \mathrm{C}$ ) for seven days. Filtered HP20 and cells were washed with $\mathrm{H}_{2} \mathrm{O}$ and extracted with acetone. The acetone extract $(3.5 \mathrm{~g})$ was subjected to liquid-liquid partitioning using $30 \%$ aqueous $\mathrm{MeOH}$ and $\mathrm{CHCl}_{3}(1: 1)$. The $\mathrm{CHCl}_{3}$-soluble partition $(2.5 \mathrm{~g})$ was fractionated by Sephadex LH20 column chromatography (column size $\mathrm{CHCl}_{3}: \mathrm{MeOH}, 1: 1$ ). Fractions containing 1 and $\mathbf{2}$ were subjected to RP HPLC (55\%/45\% to $\left.75 \% / 25 \% \mathrm{MeOH} / \mathrm{H}_{2} \mathrm{O}, 15 \mathrm{~min}, 3 \mathrm{~mL} / \mathrm{min}\right)$ using a Phenomenex Onyx Monolithic C18 column $(100 \times 4.6 \mathrm{~mm})$, yielding $2\left(3.0 \mathrm{mg}, t_{\mathrm{R}} 7.1 \mathrm{~min}\right)$ and $\mathbf{1}\left(3.2 \mathrm{mg}, t_{\mathrm{R}} 11.0 \mathrm{~min}\right)$. 
For production of 3 and $\mathbf{4}$, the amount of $\mathrm{KBr}$ in medium $\mathrm{ASW}-\mathrm{A}$ was increased from $0.1 \mathrm{~g} / \mathrm{L}$ to $10 \mathrm{~g} / \mathrm{L}$, and no $\mathrm{NaCl}$ was included. After fermentation of $500 \mathrm{~mL} \mathrm{ASW}$-A (with $\mathrm{KBr}$ ), the same isolation procedure was used. One additional purification step by RP HPLC (70\%/30\% to 76\%/24\% $\left.\mathrm{ACN} / \mathrm{H}_{2} \mathrm{O}, 11 \mathrm{~min}, 4 \mathrm{~mL} / \mathrm{min}\right)$ using a Phenomenex Luna $\mathrm{C} 18$ column $(250 \times 10 \mathrm{~mm}, 5 \mu \mathrm{m})$ yielded $3\left(1.3 \mathrm{mg}, t_{\mathrm{R}} 8.8 \mathrm{~min}\right)$ and $4\left(1.2 \mathrm{mg}, t_{\mathrm{R}} 9.1 \mathrm{~min}\right)$.

Halomadurone A (1). White solid; UV (MeOH) $\lambda_{\max }(\log \varepsilon) 204$ (3.96), 223 (3.99), 255 (3.90), 315 (3.92) nm; IR (ATR) $v_{\max } 1644,1635,1394,1215 \mathrm{~cm}^{-1} ;{ }^{1} \mathrm{H}$ and ${ }^{13} \mathrm{C}$ NMR (See Table 1); HRMS $[\mathrm{M}+\mathrm{H}]^{+} m / z 307.0044$ (calcd. for $\mathrm{C}_{13} \mathrm{H}_{14} \mathrm{Cl}_{3} \mathrm{O}_{2}, 307.0054$ ).

Halomadurone B (2). White solid; UV (MeOH) $\lambda_{\max }(\log \varepsilon) 204$ (4.04), 222 (3.94), 253 (3.79), 315 (3.83) nm; IR (ATR) $v_{\max } 1641,1632,1602,1369,932 \mathrm{~cm}^{-1} ;{ }^{1} \mathrm{H}$ and ${ }^{13} \mathrm{C}$ NMR (See Table 1); HRMS $[\mathrm{M}+\mathrm{H}]^{+} m / z 273.0453$ (calcd. for $\mathrm{C}_{13} \mathrm{H}_{15} \mathrm{Cl}_{2} \mathrm{O}_{2}, 273.0444$ ).

Halomadurone C (3). White solid; $[\alpha]_{\mathrm{D}}^{25} \pm 0 \mathrm{UV}(\mathrm{MeOH}) \lambda_{\max }(\log \varepsilon) 206$ (4.02), 253 (3.40), 324 (3.50) nm; IR (ATR) $v_{\max } 1650,1601,1396,1215,934 \mathrm{~cm}^{-1} ;{ }^{1} \mathrm{H}$ and ${ }^{13} \mathrm{C}$ NMR (See Table 1); HRMS $[\mathrm{M}+\mathrm{H}]^{+} m / z 316.9937$ (calcd. for $\mathrm{C}_{13} \mathrm{H}_{15} \mathrm{BrClO}_{2}, 316.9938$ ).

Halomadurone D (4). White solid; (c 0.12, MeOH); UV (MeOH) $\lambda_{\max }(\log \varepsilon) 206$ (4.30), 255 (3.42), 324 (3.42) nm; IR (ATR) $v_{\max }$ 1651, 1601, 1396, 1215, $934 \mathrm{~cm}^{-1} ;{ }^{1} \mathrm{H}$ and ${ }^{13} \mathrm{C}$ NMR (See Table 1); HRMS [M + H] ${ }^{+} m / z 360.9433$ (calcd. for $\mathrm{C}_{13} \mathrm{H}_{15} \mathrm{Br}_{2} \mathrm{O}_{2}, 360.9433$ ).

2-Methyl-6-((E)-3-methyl-1,3-hexadiene)- $\gamma$-pyrone (5). To a solution of 2-6-dimethyl- $\gamma$-pyrone $(1.24 \mathrm{~g})$ in $15 \mathrm{~mL}$ ethanol was added 2-methyl-2-pentenal $(2.28 \mathrm{~mL})$ and sodium ethoxide $(680 \mathrm{mg})$ in $7.5 \mathrm{~mL}$ ethanol. The reaction mixture was stirred for $5 \mathrm{~h}$ at $\mathrm{rt}$. After $5 \mathrm{~h}$, dilute $\mathrm{HCl}$ was added to the mixture and dried under vacuum. The reaction mixture was subjected to RP HPLC (40\%/60\% to $100 \% / 0 \% \mathrm{MeOH} / \mathrm{H}_{2} \mathrm{O}$ containing $0.1 \%$ acetic acid, $20 \mathrm{~min}$ ) using a Phenomenex Gemini $\mathrm{C} 18$ column $(100 \times 30 \mathrm{~mm}, 5 \mu \mathrm{m})$. Additional purification of the fraction containing 5 was conducted by Normal Phase HPLC (60\%/40\% to $100 \% / 0 \%$ ethyl acetate/hexanes, $30 \mathrm{~min})$ using a Phenomenex Luna Silica column $(250 \times 10 \mathrm{~mm}, 5 \mu \mathrm{m})$, yielding $5\left(4.0 \mathrm{mg}, 2.0 \%\right.$ yield, $\left.t_{\mathrm{R}} 25.5 \mathrm{~min}\right)$ as a white solid; UV (MeOH) $\lambda_{\max }(\log \varepsilon) 208$ (3.99), 227 (4.00), 314 (4.17) nm; IR (ATR) $v_{\max }$ 1655, 1597, 1398, 1217, $925 \mathrm{~cm}^{-1} ;{ }^{1} \mathrm{H}$ and ${ }^{13} \mathrm{C}$ NMR (See Supporting Information); HRMS [M $\left.+\mathrm{H}\right]^{+} \mathrm{m} / z 205.1230$ (calcd. for $\left.\mathrm{C}_{13} \mathrm{H}_{17} \mathrm{O}_{2}, 205.1223\right)$.

\subsection{Bioasssay hPAP and MTS}

Primary cortical neuronal cultures were derived from ARE-hPAP reporter mice as previously described [10,11]. Compounds were dissolved in 100\% DMSO and administered to cells for $48 \mathrm{~h}$. Tert-butylhydroquinone ( $t$ BHQ) was used as a control. After $48 \mathrm{~h}$, Nrf2 activation was determined by measuring for hPAP activity as previously described [32]. Using one-second integration luminescence was measured on a Berthold Orion microplate luminometer (Berthold Technologies GmbH \& Co., Bad Wildbad, Germany). Baseline signals from hPAP negative control culture samples were subtracted from all values. Cell viability was assayed using the MTS assay following the manufacturer's suggested protocol (Promega, Madison, Wisconsin, USA). All hPAP and MTS data are represented as mean \pm SEM $(n=4)$. Results of hPAP assays are expressed as the fold increase in hPAP activity over 
basal levels. Statistical analysis was performed using one-way ANOVA followed by Newman-Keuls multiple comparison (GraphPad Prism, version 4). A $p<0.05$ was considered statistically significant.

\section{Conclusions}

We reported the isolation and structure elucidation of halomadurones A-D (1-4), novel halogenated electrophilic pyrones from an Actinomadura sp. and the synthesis of a non-halogenated analogue, 2-methyl-6-((E)-3-methyl-1,3-hexadiene)- $\gamma$-pyrone (5). Halomadurones C (3) and D (4) demonstrated potent Nrf2-ARE activation. Therefore, halomaudrones A-D (1-4) could play an important role in the discovery of new therapeutics, especially considering the ever-present need for therapeutics for neurodegenerative diseases.

\section{Acknowledgments}

This work was supported by funding from the University of Wisconsin-Madison School of Pharmacy, the Graduate School at the University of Wisconsin, and the UW College of Agriculture and Life Sciences. This work was also funded by the NIH, NIGMS Grant R01 GM092009, and in part by R01 GM104192. We would like to thank the Analytical Instrumentation Center at the University of Wisconsin-Madison for the facilities to acquire spectroscopic data. This study made use of the National Magnetic Resonance Facility at Madison, which is supported by NIH grants P41RR02301 (BRTP/NCRR) and P41GM66326 (NIGMS). Additional equipment was purchased with funds from the University of Wisconsin, the NIH (RR02781, RR08438), the NSF (DMB-8415048, OIA-9977486, BIR-9214394), and the USDA. We would like to thank Don Demaria for assistance with collection, and Weiping Tang for helpful synthesis discussions.

\section{Conflicts of Interest}

The authors declare no conflict of interest.

\section{References}

1. Menken, M.; Munsat, T.L.; Toole, J.F. The global burden of disease study: Implications for neurology. Arch. Neurol. 2000, 57, 418-420.

2. Hebert, L.E.; Weuve, J.; Scherr, P.A.; Evans, D.A. Alzheimer disease in the United States (2010-2050) estimated during the 2010 census. Neurology 2013, 80, 1778-1783.

3. Alzheimer's Disease International. World Alzheimer Report 2009; Prince, M., Jackson, J., Eds.; Alzheimer's Disease International: London, UK, 2009.

4. Uttara, B.; Singh, A.V.; Zamboni, P.; Mahajan, R.T. Oxidative stress and neurodegenerative diseases: A review of upstream and downstream antioxidant therapeutic options. Curr. Neuropharmacol. 2009, 7, 65-74.

5. De Vries, H.E.; Witte, M.; Hondius, D.; Rozemuller, A.J.M.; Drukarch, B.; Hoozemans, J.; van Horssen, J. Nrf2-induced antioxidant protection: A promising target to conteract ROS-mediated damage neurodegenerative disease? Free Radic. Biol. Med. 2008, 45, 1375-1383. 
6. Calkins, M.J.; Johnson, D.A.; Townsend, J.A.; Vargas, M.R.; Dowell, J.A.; Williamson, T.P.; Kraft, A.D.; Lee, J.-M.; Li, J.; Johnson, J.A. The Nrf2/ARE pathway as a potential therapeutic target in neurodegenerative disease. Antioxid. Redox Signal. 2009, 11, 497-508.

7. Vanugopal, R.; Jaiswal, A.K. Nrf1 and Nrf2 positively and c-Fos and Fra1 negatively regulate the human antioxidant response element-mediated expression of $\mathrm{NAD}(\mathrm{P}) \mathrm{H}$ :quinone oxidoreductase $\mathrm{e}_{1}$ gene. Proc. Natl. Acad. Sci. USA 1996, 93, 14960-14965.

8. Itoh, K.; Ishii, T.; Wakabayashi, N.; Yamamoto, M. Regulatory mechanism of cellular response to oxidative stress. Free Radical Res. 1999, 31, 319-324.

9. Wild, A.C.; Moinova, H.R.; Mulcahy, R.T. Regulation of $\gamma$-glutamylcysteine synthetase subunit gene expression by the transription factor Nrf2. J. Biol. Chem. 1999, 274, 33627-33636.

10. Kraft, A.D.; Johnson, D.A.; Johnson, J.A. Nuclear factor E2-related factor 2-dependent antioxidant response element activation by tert-butylhydroquinone and sulforaphane occurring preferentially in astrocytes conditions neurons against oxidative insult. J. Neurosci. 2004, 24, 1101-1112.

11. Johnson, D.A.; Andrews, G.K.; Xu, W.; Johnson, J.A. Activation of the antioxidant response element in primary cortical neuronal cultures derived from transgenic reporter mice. J. Neurochem. 2002, 81, 1233-1241.

12. Balogun E.; Hoque, M.; Gong, P.; Killeen, E.; Green, C.J.; Foresti, R.; Alam, J.; Motterlini, R. Curcumin activates the haem oxygenase- 1 gene via regulation of $\mathrm{Nrf} 2$ and the antioxidant-responsive element. Biochem. J. 2003, 371, 887-895.

13. Haridas, V.; Hanausek, M.; Nishimura, G.; Soehnge, H.; Gaikwad, A.; Narog, M.; Spears, E.; Zoltaszek, R.; Walaszek, Z.; Gutterman, J.U. Triterpenoid electrophiles (avicins) activate the innate stress response by redox regulation of a gene battery. J. Clin. Invest. 2004, 113, 65-73.

14. Shibuya, A.; Onda, K.; Kawahara, H.; Uchiyama, Y.; Nakayama, H.; Omi, T.; Nagaoka, M.; Matsui, H.; Hirano, T. Sofalcone, a gastric mucosa protective agent, increases vascular endothelial growth factor via the Nrf2-heme-oxygenase-1 dependent pathway in gastric epithelial cells. Biochem. Biophys. Res. Commun. 2010, 398, 581-584.

15. Lee, Y.M.; Jeong, G.S.; Lim, H.D.; An, R.B.; Kim, Y.C.; Kim, E.C. Isoliquiritigenin 2'-methyl ether induces growth inhibition and apoptosis in oral cancer cells via heme oxygenase-1. Toxicol. Vitro 2010, 24, 776-782.

16. Wang, R.; Mason, D.E.; Choe, K.P.; Lewin, A.S.; Peters, E.C.; Luesch, H. In vitro and in vivo characterization of a tunable dual-reactivity probe of the Nrf2-ARE Pathway. ACS Chem. Biol. 2013, 8, 1764-1774.

17. Wang, R.; Paul, V.; Luesch, H. Seaweed extracts and unsaturated fatty acid constituents from the green alga Ulva lactuca as activators of the cytoprotective Nrf2-ARE pathway. Free Radic. Biol. Med. 2013, 57, 141-153.

18. Orjala, J.; Gerwick, W.H. Barbamide, a chlorinated metabolite with molluscicidal activity from the Caribbean cyanobacterium Lyngbya majuscula. J. Nat. Prod. 1996, 59, 427-430.

19. Jiménez, J.I.; Scheuer, P.J. New lipopeptides from the Caribbean cyanobacterium Lyngbya majuscula. J. Nat. Prod. 2001, 64, 200-203.

20. Nozoe, S.; Ishii, N.; Kusano, G.; Kikuchi, K.; Ohta, T. Neocarzilins A and B, novel polyenones from Streptomyces carzinostaticus. Tetrahedron Lett. 1992, 33, 7547-7550. 
21. Nozoe, S.; Kikuchi, K.; Ishii, N.; Ohta, T. Synthesis of neocarzilin A: An absolute sterochemistry. Tetrahedron Lett. 1992, 33, 7551-7552.

22. Otsuka, M.; Ichinose, K.; Fujii, I.; Ebizuka, Y. Cloning, sequencing, and functional analysis of an iterative type I polyketide synthase gene cluster for biosynthesis of the antitumor chlorinated polyenone neocarzilin in "Streptomyces carzinostaticus". Antimicrob. Agents Chemother. 2004, $48,3468-3476$.

23. Hou, Y.; Braun, D.R.; Michel, C.R.; Klassen, J.L.; Adnani, N.; Wyche, T.P.; Bugni, T.S. Microbial strain prioritization using metabolomics tools for the discovery of the natural products. Anal. Chem. 2012, 84, 4277-4283.

24. Zeng, J.; Zhan, J. A novel fungal flavin-dependent halogenase for natural product biosynthesis. ChemBioChem 2010, 11, 2119-2123.

25. Vaillancourt, F.H.; Vosburg, D.A.; Walsh, C.T. Dichlorination and bromination of a Threonyl-S-carrier protein by the non-heme FeII halogenase SYRB2. Chembiochem 2006, 7, $748-752$.

26. Williams, D.H.; Fleming, I. Spectroscopic Methods in Organic Chemistry, 4th ed.; McGraw-Hill Book Company Limited: London, UK, 1989.

27. Eustaquio, A.S.; Pojer, F.; Noel, J.P.; Moore, B.S. Discovery and characterization of a marine bacterial SAM-dependent chlorinase. Nat. Chem. Biol. 2008, 4, 69-74.

28. Wagner, C.; El Omari, M.; König, G.M. Biohalogenation: Nature's way to synthesize halogenated metabolites. J. Nat. Prod. 2009, 72, 540-553.

29. Ghandi, M.; Bayat, Y.; Teimuri-mofrad, R. A novel method for the synthesis of formyl and hydroxymethyl derivatives of 4H-pyran-4-one. Org. Prep. Proced. Int. 2002, 34, 525-530.

30. Satoh, T.; McKercher, S.R.; Lipton, S.A. Nrf2/ARE-mediated antioxidant actions of pro-electrophilic drugs. Free Radical Biol. Med. 2013, 65, 645-657.

31. Wyche, T.P.; Hou, Y.; Braun, D.; Cohen, H.C.; Xiong, M.P.; Bugni, T.S. First natural analogs of the cytotoxic thiodepsipeptide thiocoraline A from a marine Verrucosispora sp. J. Org. Chem. 2011, 76, 6542-6547.

32. Fischedick, J.T.; Standiford, M.; Johnson, D.A.; Johnson, J.A. Structure activity relationship of phenolic diterpenes from Salvia officinalis as activators of the nuclear factor E2-related factor 2 pathway. Bioorg. Med. Chem. 2013, 21, 2618-2622.

(C) 2013 by the authors; licensee MDPI, Basel, Switzerland. This article is an open access article distributed under the terms and conditions of the Creative Commons Attribution license (http://creativecommons.org/licenses/by/3.0/). 